\title{
Humanities and Sciences as Complementary Aspects of an Afrikan=Black Whole: Evidence from Archeoastronomy
}

\section{Ọbádélé Bakari Kambon}

\author{
Senior Research Fellow \\ Language, Literature and Drama Section \\ Institute of African Studies, College of Humanities \\ University of Ghana - Legon \\ Email: obkambon@ug.edu.gh \\ Yaw Mankatah Asare \\ Graduate Assistant \\ Institute of African Studies, College of Humanities \\ University of Ghana, Legon, Ghana \\ Email: asarenoah@gmail.com
}

Submitted: January 14, 2019/ Accepted: September 24, 2019 /Published: December 30, 2019

\begin{abstract}
In ancient Afrika ${ }^{1}$, science, technology, engineering and mathematics were not seen as separate from or at odds with what is now referred to in English as the Humanities. Focusing on archeoastronomy of Kmt 'land of Black people (i.e. Ancient Egypt)', we demonstrate that the scientific principles used to build pyramids, temples, and other edifices were rooted in and fused with Afrikan systems of deep thought and spirituality. The method adopted in this study examines alignments of structures of $K m t$ 'land of Black people' with respect to solar and celestial phenomena in an attempt to establish systematic patterns and correlations between architectural alignments and astronomical phenomena. This method is adopted to show the relationship between structures constructed and knowledge of the oneness of humanities and sciences. Therefore, in this study, we find that the dichotomization and fragmentation of knowledge and disciplines should move towards a more holistic $\square \frac{\square m t y w}{1}$ 'Black people, people of Kmt' perspective.

Keywords: archeoastronomy, complementarity, archeogeography, STEAM, Kmt

\footnotetext{
${ }^{1}$ As I have argued elsewhere, while not ideal, Afrika (n.)/Afrikan (adj.) is preferred to "Africa" as the word is consistently spelled in various Afrikan languages with a /k/ (cf. Yorùbá Áfríkà; Akan Afrika; Kiswahili Afrika; isiZulu iAfrika; Kikongo Afelika; Hausa Afirka; Kirundi Bufirika; Gĩkũyũ Abĩrika; Igbo Afrịka; Luganda Afirika; Lingála Afríka; Malagasy Afrika; Sesotho sa Leboa Afrika; Oromoo Afrikaa; Fulfulde Afirik; Setswana Aferika; Tsivenda Afurika; Tsisonga Afrika; Siswati Í-Afríka; Soomaaliga Afrika; Kinyarwanda Afurika, etc.) noting that Afrikan languages by-and-large do not use a /c/ for a hard $/ \mathrm{k} /$ sound. Because of the aforementioned consideration, this spelling has been advanced and preferred since the 1960s by various Afrikan-Centered individuals, movements and organizations of the continent and diaspora such as Llaila O. Afrika, the Republic of New Afrika, Afrika Youth Movement, the Afrikan-Centered Education movement, the Afrikan-Centered Psychology movement, the New Afrikan Prison Struggle, AfrikanWorldAnalysis.com, Inspire Afrika, Step Afrika!, etc.
} 


\section{Introduction and Background}

In this paper, we will articulate the view that, from an Afrikan-centered perspective, the Humanities and Sciences were seen as complementary aspects of a whole. By way of definition, the term complementary denotes "Combining in such a way as to enhance or emphasize the qualities of each other or another" (Stevenson, 2010, p. 356). From another definition, it refers to "completing something else or making it better: serving as a complement - used of two things when each adds something to the other or helps to make the other better: going together well: working well together" (Merriam-Webster, 2018a). It is in this vein that we will examine the Afrikan precedents of what are now disparately categorized as Humanities and Sciences.

Qualitative in nature, traditionally the Humanities as a collective comprises the following: "Liberal arts, arts, literature; classics, classical studies, classical languages, classical literature; Latin - literae humaniores" (Waite, 2009, p. 429). According to Merriam Webster, The Humanities relates to "the branches of learning (such as philosophy, arts, or languages) that investigate human constructs [...] and concerns as opposed to natural processes (as in physics or chemistry) and social relations (as in anthropology or economics)" (Merriam-Webster, 2018b). However, this type of definition begs the question of where is the intersection of these branches of learning? Not to deprecate the analogy, branches stem from a common tree with common roots.

It also may be noted that for many, science may not be so much of a field of knowledge, but rather a 'systematized' way of knowing (i.e., that which conforms to the scientific method). Used traditionally, however, the sciences tend to take a quantitative approach towards knowing. This includes Algebra, Agriculture, Chemistry, Biology, Physics, and Mathematics.

Looking at the term from an etymological perspective, science denotes "what is known, knowledge (of something) acquired by study; information;" with a strong correlation with the scientific method. It is derived from the Latin scientia "knowledge, a knowing; expertness,"

from sciens (genitive scientis) "intelligent, skilled," present participle of scire "to know," probably originally "to separate one thing from another, to distinguish," related to scindere "to cut, divide," from PIE root *skei- "to cut, split" (source also of Greek skhizein "to split, rend, cleave," Gothic skaidan, Old English sceadan "to divide, separate") (Etymonline, 2018).

In modern times, the sciences and the humanities are seen and treated as divided and separated from each other conceptually as well as in implementation for the purposes of intellectual categorization. For example, at the University 
Kambon, B. O. \& Asare, Y. M./Humanities and Sciences as Complementary Aspects of an Afrikan=Black Whole: Evidence from Archeoastronomy

of Ghana, the College of Humanities is separate from the College of Basic and Applied Science. However, in classical Afrika, $K m t$ "land of Black people", contemporarily known as so-called Ancient Egypt and its predecessor civilizations deeper into the interior of Afrika in the south this was not the de facto state of affairs. $^{2}$

To put things in perspective in terms of trajectory of Afrikan thought and practice in this regard, it is necessary to look at the origins of these studies and how they persist throughout Afrikan space and time. In this vein, according to Diop, "The history of Africa will remain suspended in air and cannot be written correctly until African historians connect it with the history of Egypt [...] The African historian who evades the problem of Egypt is neither modest or objective, nor unruffled, he is ignorant, cowardly, and neurotic" (Diop \& Cook, 1989, p. xiv). Therefore, it is of the utmost importance for us to understand the relationships between $\mathrm{Kmt}$ "land of Black people" and its parent civilizations to the south. ${ }^{3}$

In Ancient Afrika and more recent pre-conquest-by-Eurasians Afrika, the Humanities and the Sciences were demonstrably seen as complementary aspects of an Afrikan whole. Further, those pursuits, which are now referred to as Sciences and Humanities in English, coexisted and were in no way separated has been discussed by a few other scholars (Browder, 1992; Finch, 1998; Obenga, 2004; Van Sertima, 1983). Separation and dichotomization, however, form the conditio sine qua non, of Eurasian thought. Ani (1994) defines dichotomization in Eurasian thought as:

A mechanism which accompanies objectification. It is the splitting of [a] phenomenon into confrontational, conflicting parts. It facilitates the pursuit of power over other, and is therefore suited to the European Asili (Ani, 1994, p. xxviii).

Writing further with regard to the Eurasian thrust for dichotomization, in this process:

All realities are split into two parts. This begins with the separation of self from "other," and is followed by the separation of the self into various dichotomies (reason/emotion, mind/body, intellect/nature). The process continues until the universe is composed of disparate entities (Ani, 1994, p. 105).

The above leads us to the underlying premise of our article where we hone the idea that it is un-Afrikan to compartmentalise Afrikan knowledge, thought and practise as they mutually complement each other. In fact, Kreamer (2012) attests to this fact when writing on the cosmology of Afrikans as echoed by the arts. She notes in the introduction of the book African Cosmos that Afrikans

\footnotetext{
${ }^{2}$ The use of "so-called" here implies that this is not how the indigenes referred to the country, it is rather a name that has been imposed upon the land by non-Afrikans.

${ }^{3}$ See Van Sertima, I. (1994). Egypt: Child of Africa. New Brunswick, NJ: Transaction Publishers. (Van Sertima, 1994).
} 
take a "holistic approach toward comprehending reality" (p. 15). This is because bodies of knowledge are not compartmentalised but rather integrated thus serving as complements. Ideas of complementary opposites are also attested by Obenga (Obenga, 2004) speaking about the key aspect highlighted in the Ahmes (Rhind) papyrus, which is:

the necessity for a correct method (tp-hsb), to be used in directing human intelligence in its effort to understand reality. The method envisaged is obviously the science of mathematics. For the ancient Egyptian conception of mathematics required that the abstract sciences, for which correct method is a prerequisite, be complemented by the applied and technical sciences (Obenga, 2004, p. 434) (bold emphasis added).

Thus, a major difference between Afrikan thought and Eurasian thought, therefore is the distinction between complementary opposites and dichotomous diametric opposites. In this paper we lay bare many manifestations of Afrikan conceptions of complementary opposites drawing from examples from throughout the global Afrikan world. We maintain that the Afrikan Science of Astronomy and associated mathematical calculations utilized analogical reasoning to inform Architecture, Philosophy, Spirituality and Literature and vice-versa as the abstract complemented the physical. Analogical reasoning allows for one to grasp knowledge and extrapolate knowledge from one field to another to solve problems. Thus, at the core of religious symbols, rituals, and arts laid a complex understanding of astronomy (Hilliard, 1998; Womack, 2013).

With regard to astronomy, the Celestial Sphere - characterised and replicated on Earth - was and is still conceptualised as worldview. This profound concept whose core principles form the foundation of Afrikan society connotes the concepts of Truth, Justice, Righteousness/Propriety, Harmony, Balance, Order, Reciprocity. However, Beatty (1997) warns us about seeing $M_{3}{ }^{\varsigma} t$ 'Maat' in fragmented perspectives as opposed to a holistic concept signalling 'universal order'. For Beatty,

"Because Maat is not an object, it cannot be known as an object. Maat is not a Newtonian machine with isolated or separate parts interacting by law. Maat does not have distinct parts or entities, but possesses interrelated and interconnected manifestations of a cosmic whole. It is a we awareness that does not divide up the world into separate and self-contained units. Distinctions are made, yet there is never any fragmentation (p. 216).

$\Rightarrow M^{9} t$ 'Maat' is thus a fractal principle of a microcosm reflecting the macrocosm of universal order that sustains/governs the cosmos and, as such, it manifests in various ways in the physical world. Beyond this, in the language of 7. $m d w n t r$ 'Divine Words/Hieroglyphs', all nouns are masculine or feminine. 
$\Rightarrow \mathrm{N}^{9} \mathrm{t}$ 'Maat' is represented as a woman with an ostrich feather. As such, to even refer to $\Rightarrow 0 M^{9} t$ 'Maat' as "it" may miss the point of $\Rightarrow$ as "she" in the worldview of the $\square$ get a sense of three levels of the manifestations of Maat by reading Obenga (2004):

- The first manifestation is on a Universal level where all things in the cosmos are aligned.

- The second manifestation is political where the ruler organises his people to cast out isft for the restoration of balance, Ma'at. On the political level, the concept of Ma'at works against injustice. It is in the name of Ma'at that the pharaoh subjugates rebels and dominates foreign lands.

- $\quad$ On the individual level, "Maat embraces specific rules for living in concert with moral principles." Whoever lives according to these rules and principles achieves universal order in his or her own life, in practical terms, and lives in harmony with the ordered Whole. The most accomplished, useful and appropriate human actions are circumscribed in the cosmological order, as symbolized by the way the pharaoh's name is written inside a circular cartouche, a perfect geometrical shape representing the vitalizing Sun (Obenga, 2004, pp. 191-192).

While all three levels of this multi-layered view are clearly interrelated, in this paper, we focus on the first two aspects of evidence from archaeoastronomy and other related areas that demonstrate the science related to humanistic endeavours such as "temple-building."

Desires to fulfil the 'harmonious interaction' and 'co-existence' of the physical and cosmological plane are manifested in the architectural genius of Kmt 'Land of Black people.' Architecture is a concrete manifestation of the vision of a people. As people in sun and stars, architecture was constructed to reflect this vision. However, for this vision to be materialised it demanded that one had an intimate knowledge of the movement of the stars and the sun in order to actualize the concept of "as above, so below" (Chandler, 2000, p. 28; Martin, 2008, p. 957).

It is worth noting that far from alignments of monumental and structures being an invention in the nation of $K m t$ 'Land of Black people,' deep in the southern interior of Afrika there was a megalithic calendar circle aligned with 
certain stars at a place now referred to as Nabta Playa. According to Brophy and Rosen (2005):

The report that a primary megalithic alignment was constructed to point to the bright star Sirius, circa 4,820 BC, is reconsidered in light of the satellite data, new field data, radiocarbon, lithostratigraphic and geochronologic data, and the playa sedimentation history. Other possible archaeoastronomical interpretations are considered for that alignment, including the three star asterism (of Alnitak, Alnilam, and Mintaka) circa 6,270 BC that is also implicated in the small Nabta Playa 'calendar circle' (p. 15).

Interestingly, the calendar circle of Nabta Playa was located in the area known as Nubia and which now forms part of southern Egypt and was created a few thousand years before the most conservative dates given for the unification of $\square K m t$ 'land of Black people' under acknowledged unifier of upper (southern) and lower (northern) $\square$ Kmt 'land of Black people'.

The stone megaliths found in the Nubian desert, Nabta Playa, also echo a strong sense of astronomical knowledge, requiring scientific study, observation and acute scientific calculation. Malville, et al. (2007) discuss the astronomy of Nabta Playa pointing to three pieces of evidence of astronomical knowledge:

1. the repeated positioning of "megaliths, stele, human burials and cattle burials toward the northern regions of the sky"

2. the cromlech on the site as shown by Wendorf and Schild also show an orientation of "two sightlines toward the north and toward the rising sun at the June solstice"

3. the orientation of the stele towards the brightest stars, Nabta, Sirius, $\alpha$ centauri, Arctus and Canopus in the celestial realm of the Nabta skies (McK Malville et al., 2007, p. 6)

Thus, while we will look extensively at temple orientations of $\mathrm{Kmt}$ 'land of Black people', it is imperative for us to understand that $\mathrm{Kmt}$ 'land of Black people' should not be seen as isolated from other Black people of its parent civilizations in the interior of Afrika to the south or restricted to ancient pre-history. In fact, a more recent archaeo-astronomical site organized along similar lines is known as Namoratunga II. Namoratunga II is located to the west of Kenya's Lake Turkana in Kenya and is thought to have been created around 300 все. Namoratunga II, which translates to "people of stone" in the Turkana language prominently features a formation of stone encircling 19 basalt pillars 
arranged in alignment with the star systems of Aldebaran, Bellatrix, Central Orion, Pleiades, Saiph, Sirius and Triangulum. The basalt pillars are thought to be linked to the constellations associated with the 12-month lunar calendar of 354 days used by Cushitic speakers of southern Ethiopia (Lynch \& Robbins, 1978).

Cosmological symbolisms of directional orientations are also evident among the Dogon people of Mali as found in Conversations with Ogotemmeli, a collection of philosophical teachings reported by Griaule from Ogotemmeli in the 1930s (Griaule, 1934 (1970)). Implicit in the structural positioning of a Dogon community is the knowledge of cardinal positions as illustrated by Griaule. In his illustration of the village, we see that the village is oriented towards the north. The village is personified as a person laying on their back with the head facing north. Griaule reports that Dogon beds are oriented towards a N-S position where the head always faced North. This cardinal positioning also informed the sleeping positions and the burial positioning of both genders. Griaule reports "The man lies on his right side facing west, and the woman on her left side facing east, which are the positions they will occupy in the grave" (Griaule, 1934 (1970), p. 95). This intentional structural positioning of the bed, grave and village reflects, as noted above, the incorporation and complementarity of scientific knowledge with that of cultural practices as well as stressing analogical reasoning as a human is geographically and architecturally defined.

While the orientations are different, we find the shared worldview of ensuring specific placement with regard to cardinal directions in the grave transcends time dating back to the late Pleistocene era. Indeed, the Jebel Sahaba cemetery, a Mesolithic site dated to 14,340 to 13,140 years and located in the Nile Valley in Nubia (Northern Sudan) is notable for Afrikans buried in the fetal position facing south and with their heads oriented toward the east as shown in Figure 1 (Graham, 2016). 


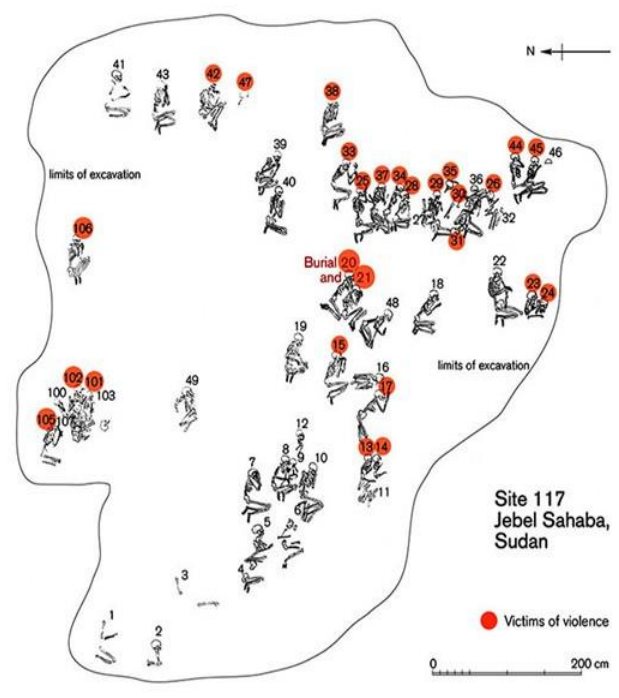

Figure 1: Map of cemetery 117 at Jebel Sahaba: Afrikans buried in the fetal position facing south and with their heads oriented toward the east (Image Credit British Museum, 2019)

Orientations toward significant cardinal directions is also evinced in other parts of the continent as we will show below.

With regard to the south of $K m t$ 'land of Black people' it is also important to note that the orientation of the map for Afrikans was South-Up. In $m d w n t r$, it is clear that $\stackrel{t}{\phi} ل_{1} i z b t$, the word for East is the same as the word for left, and the word imn 'West', is the same as the word for right as well as all other derivative words. Further, $s m^{\varsigma} w$ 'Upper Kmt' was synonymous with $r s y$ 'the South' and the $m h w$ 'lower Kmt' was associated with $m h t t$ 'North' (Carruthers, 1989, pp. 22-23). This spatial orientation can be seen in what is regarded by cartographers as the oldest map of topological significance known as the Turin Papyrus Map created by scribe 'Amennakhte' ca. 1150 все. This map has a South-Up orientation showing a 15kilometre stretch to the mines of Wadi Hammamat (Harrell \& Brown, 1992a, 1992b; McMahon, 1992). According to Carruthers (1999): 
Kambon, B. O. \& Asare, Y. M./Humanities and Sciences as Complementary Aspects of an Afrikan=Black Whole: Evidence from Archeoastronomy

Our ancestors, the ancient Kemites (i.e., Egyptians) ${ }^{4}$ equated up with South and down with North. Upper Kemet (Egypt) is in Southern Egypt and Lower Egypt is in the North. The Nile flows down from the Equator to the Mediterranean Sea. Pharaoh Jehewty-Mose asserted: "My southern boundary is at the top of the world." Quite possibly the Kemites considered the Equator as the top of the world (p. 262).

This reflects a $\odot 1$ 题 Ra-centered view based on the ecliptic in that "from the perspective of a person in the northern hemisphere facing the equator, the sun would appear to rise on the left and set on the right. From the position of a person in the southern hemisphere, however, the sun would appear to rise on the right and set on the left" (Kambon, 2017, p. 24).

\section{Archeoastronomy as Evidence of Complementarity between "The Humanities" and "The Sciences"}

$\square$

The method adopted in this study examines alignments of structures of an attempt to establish systematic patterns and correlations between architectural alignments and astronomical phenomena. This method is adopted to show the relationship between structures constructed and knowledge of the oneness of humanities and sciences. According to Seba Montgomery, "In Kemet, the temples stand as testimony to the importance and the functionality of their star knowledge (Montgomery, 2017, p. 4). In a similar vein, Tata Obenga states that "Egyptian temples, like all such places of worship as lakes, shrines, pyramids, obelisks and palaces, were also expected to conform to the cosmic order of Maat. So the axes of sacred buildings were aligned with the energy vectors of the universe. Ancient Egyptians were always driven by a passionate desire to achieve unity with the entire cosmos" (Obenga, 2004, p. 604). Indeed, we find reflected in all aspects of the life of the movement of the stars and sun. This is particularly clear when we examine various architectural orientations vis-à-vis astronomical events. These astronomical events have been grouped into seven families by Belmonte et al. (2009) after an analysis of about 330 temples. This categorization is helpful for understanding these orientations as a whole complex which grew out of a worldview that sought to be in alignment with the cosmos as opposed to viewing each building as an isolated and disconnected incidence of architectural anomalies. Indeed, the orientational complex including equinoctial, solstitial, seasonal, Sopdet, Canopus, and the (mid) quarter-cardinal family accounts for the majority of the orientations of temples and other structures of ancient

\footnotetext{
${ }^{4}$ Better translated literally as Black people.
} 
at each of these families below providing a brief description before giving a more detailed account with examples following the typology developed by Belmonte et al. (2009):

1. The "equinoctial" or eastern family: Buildings in this group are oriented towards the "equinoctial sun when the disk has completely risen above the horizon" (Belmonte et al., 2009, p. 227). The equinox occurs on March 20th or 21st and September 22 or 23 . For one to orient architecture towards the equinoxes it implies the knowledge of the cardinal points which, according to Belmonte et al., stems from the explicit "observation of certain configuration of stars and constellations in the northern skies, notably Meskhetyu" ( $p$. 227).

2. The solstitial family: In this group, structures are oriented towards sunrise during $\square$ Y 期

$n n$ 'Nen/Winter Solstice'. Aapi occurs during June 20 or 21 whereas Nen occurs during December 21 or 22 . The orientation of structures like the $\Delta_{1} m r w$ 'pyramids' of Giza and the temple of $\left[\int_{1}{ }_{1} \otimes\right.$ ipt swt 'Karnak' towards the sun during the Aapi and Nen solstices is evidence of the astronomical knowledge of Afrikans=Black people. Figure 2 gives a useful illustration of the aforementioned equinoxes and solstices.

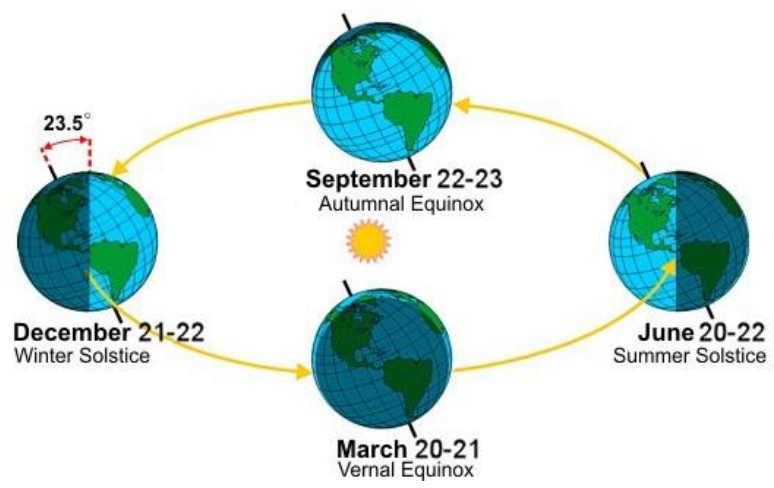

Figure 2: Equinoxes and Solstices (Weather.gov, 2018) 
Kambon, B. O. \& Asare, Y. M./Humanities and Sciences as Complementary Aspects of an Afrikan=Black Whole: Evidence from Archeoastronomy

3. The seasonal family: Buildings in this group were specially constructed to mark and record seasonal changes. 3ht 'Inundation Season' marked the flooding of the Nile

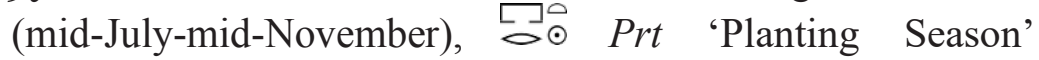
marking the time for sowing (mid-November-mid-March) and $\square S m w$ 'Harvest Season' marking the time for

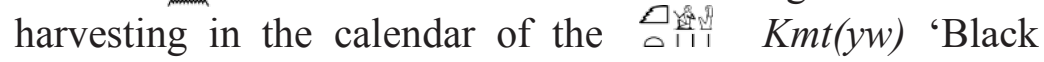
people, people of Kmt' (Mid-March-Mid-July).

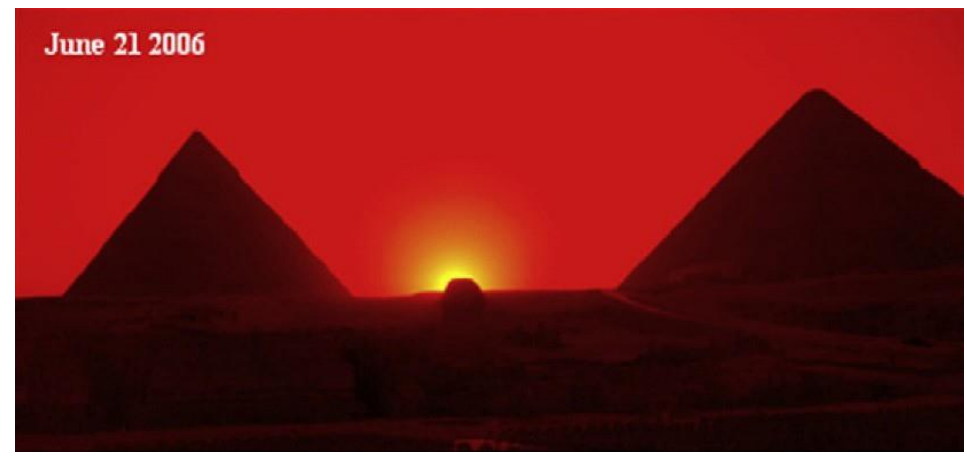

Figure 3: hr m 3ht 'Great Sphinx' at the Summer Solstice (Photo Credit Belmonte \& Shaltout, 2010, p. 535)

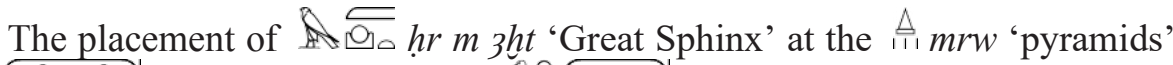

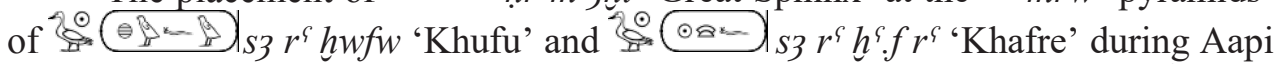
or the June solstice captured in an attemative pictorat or the June solstice captured in an alternative pictorial representation of $\triangle$ b $3 h t$ 'Akhet/horizon' as depicted in $9 \| m d w$ ntr , the sun rising between two mountains.

Allen (2015, p. 10) traces the etymology of the word 3 ht 'Akhet/horizon' to Sh, 'an effective spirit'. Thus, he argues that the eastern horizon, was known as the Akhet, meaning "Place of Becoming Effective."

This view is expounded upon by Browder (1992) as he articulates that:

Viewed from the Sphinx at the time of the summer solstice when the sun is at its greatest distance north of the celestial equator, it sets directly between the pyramids of Khufu and Khafre, thus writing across the horizon an akhet 'on the scale of acres'. This is a clear reference to Horus [Heru] the god and the akhet sign, because anyone approaching from ancient Memphis would have seen the head of the Sphinx silhouetted between the two pyramids (p. 115). 

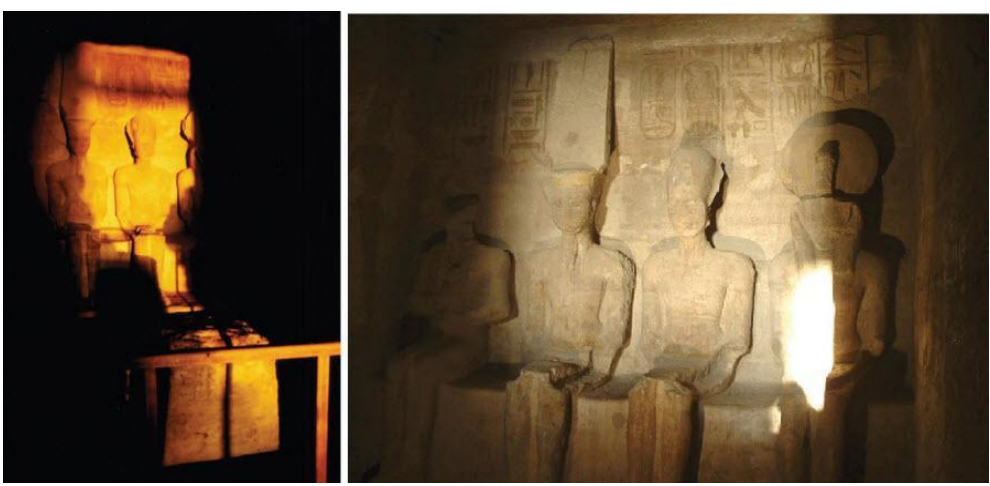

Figure 4: Light of the rising sun enters the sancta sanctorum of the main temple of Abu Simbel (Belmonte et al., 2009, p. 233)

Indeed, the indigenous term describing this monumental carving out of solid stone in $1 / m d w n \underline{t r}$ is $\overline{O_{0}} h r m$ zht 'Great Sphinx', literally 'Heru in the horizon' displaying one of the world's oldest and largest manifestations of hierophany which can still be seen today as shown in Figure 3.

Another such instance of hierophany can be viewed in the temple at $\mathrm{Abu}$

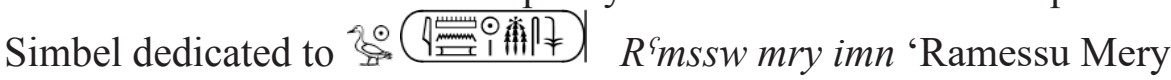
Amen', which provides an example of a building oriented towards the heliacal rising, signalling the beginning of $\longleftarrow \odot$ prt and

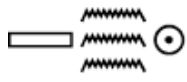
$\check{s} m w$ seasons as shown in Figure 4 and as documented by Belmonte, et al. (2009), worth quoting in full below:

At dawn on 22 February 2004, the light of the rising sun enters the sancta sanctorum of the main temple of Abu Simbel. The first rays illuminate the figures of AmonRe, the divinized king and the shoulder of Re-Horakhty, all of them gods of solar character, while the figure of Ptah, god of the netherworld, stays in darkness. When the light progresses, the figure of Re-Horakhty receives first the full and afterwards the last rays of the sun. This marvellous hierophany may have occurred at the beginning of the Peret and Shemu seasons of the ancient Egyptian calendar, during the first decades of the reign of Ramses II, the temple builder (Belmonte et al., 2009, p. 231).

4. The Sopdet family: Buildings in this family were oriented towards the rising of the brightest star in the Kmtian sky, $\triangle \underset{x}{x}$ spdt 'Sopdet/Sirius.' Belmonte, et. al (2009) put in this category structures with a declination of $-17^{3} /_{4}^{\circ}$ and $-53^{3} /^{\circ}$ an example being 
Kambon, B. O. \& Asare, Y. M./Humanities and Sciences as Complementary Aspects of an Afrikan=Black Whole: Evidence from Archeoastronomy

the temple dedicated to โอ 'Ist 'Aset/Isis' located behind the temple of

5. The Canopus family: Belmonte, et. al (2009) include in this family buildings oriented towards Canopus, the second brightest in the sky of $\triangle m t$ 'land of Black people' after $\Delta x_{s p d t}$ 'Sopdet/ Sirius'. An example of such a building with this orientation is the temple of 万人? 'Ist 'Aset/Isis', a part of the complex of temples at Philae.

6. The Meridian family: Buildings in this family were aligned with "certain configurations of stars near the celestial pole" (Belmonte et al., 2009, p. 237). We are informed that the circumpolar

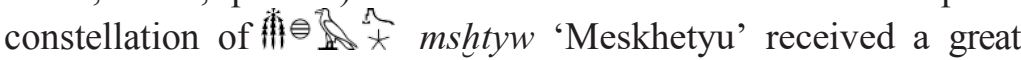
deal of attention through the orientation of the buildings, making it almost inseparable from the first family (Belmonte et al., 2009). The temple of $h r(w)$ 'Heru' at Edfu is an example.

7. The (mid) quarter-cardinal family: According to Belmonte, et al. (2009) "The quarter-cardinal family is defined as a group of temples whose orientation is close to $45^{\circ}(\mathrm{NE}), 135^{\circ}(\mathrm{SE}), 225^{\circ}(\mathrm{SW})$ or $315^{\circ}$ (NW)." He further argues that these produce "a peak at $-39^{\circ} \pm 34^{\circ}$ (VII-) and its symmetric at some $40^{\circ}$ (VII+)" (Belmonte et al., 2009, p. 238). The New Kingdom Million Year Temples of Abydos and Western Thebes are good exemplars of this group.

Having considered the above, we obtain a clear indication that astronomical knowledge complemented and informed the architectural practices of $\operatorname{Kmt}(y w)$ 'Black people, people of Kmt'.

\section{Solar Alignments}

As shown above in Figure 4, an exemplification of the marriage between now disparate Sciences and Humanities can be seen in another instance of hierophany. What is significant about hierophany as enshrined in architecture is the fact that its accomplishment is as a result of precise calculations such that $\therefore \odot \mathrm{R}^{\varsigma}$ 'the sun' will shine his light into a specifically constructed space on specific dates/times at significant celestial/solar events. That is to say, mathematical 
precision serves ultimately humanistic purposes. A further exemplification of this principle can be seen in the example in Figure 5:
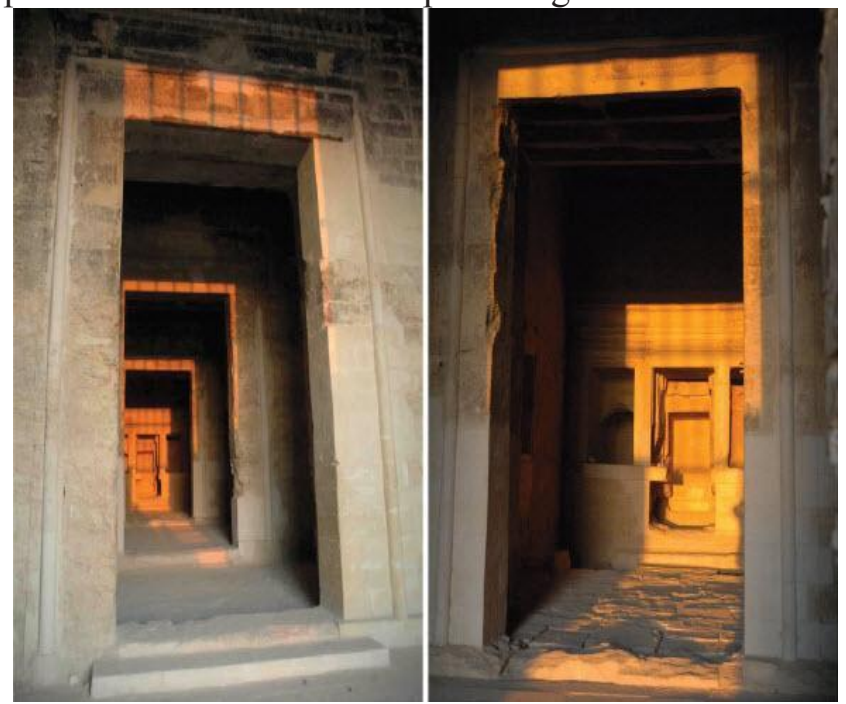

Figure 5: Light hierophany at sunrise at the winter solstice (Photo Credit Belmonte et al., 2009, p. 226)

Belmonte (2009, p. 231) gives a thorough articulation of the effect achieved in the temple of Sobek-Ra as follows:

A splendid light hierophany at sunrise at the winter solstice (December 21st 2006) at the temple of Sobek-Re in Qsar Qarun (Dionysas) in El-Fayum Oasis. Notice the illumination of the inner sanctuary (left), where the statue of the god would have been located, and of the various successive portals. The winged-disc symbol of Horus Behedety blossoms above the first gate at the pale yellow light of the first rays of his physical counterpart, the solar-disk. As the sun rises, its light moves to the north illuminating the small shrine to the right of the sanctuary while the niche to its left, where the mummy (the underworld aspect) of the god was presumably located, always remains in darkness. Notice the parallelism with the illumination phenomenon at Abu Simbel (p. 231)

Whereas in Eurasian thought, so-called religious complexes are not seen as being intrinsically related to math and science, in the astronomical alignment of spiritual structures were measured and considered from their very inception via the stretching of the cord ceremonies, ensuring accuracy of placement and orientation (Montgomery, 2017). Yet another example of this phenomenon can be seen in the orientation of the colossi of Amenhotep III, which have faced the sunrise at the time of the winter solstice for 3,350+ years in 
Kambon, B. O. \& Asare, Y. M./Humanities and Sciences as Complementary Aspects of an Afrikan=Black Whole: Evidence from Archeoastronomy alignment with the temple of millions of years (Belmonte et al., 2009, p. 216).

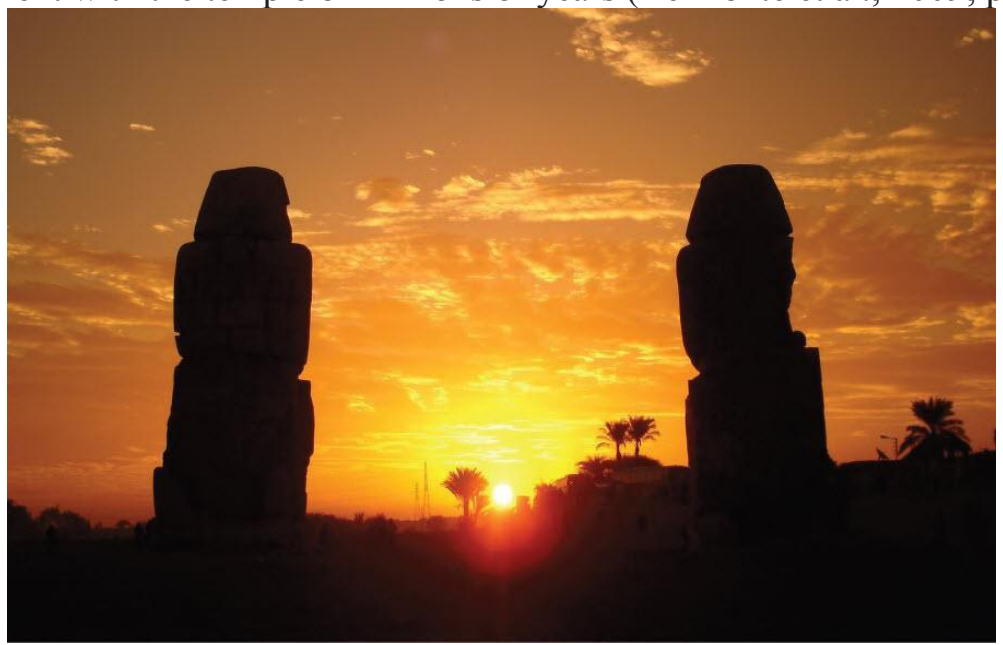

Figure 6: sunrise at the time of the winter solstice (Photograph courtesy of M. A. Molinero and N. Delgado) in (Belmonte et al., 2009, p. 216)

Yet another example of solar alignment can be found in the small temple of Aton at Akhetaton. In Figure 6, we can see clearly that the temple is oriented toward a cleft in the horizon where the royal tomb was excavated, which is the precise spot where 0 迎 $\mathrm{R}^{\varsigma}$ 'the sun' rises in late February and October. This alignment is thought to be the impetus for the name Akhetaton 'Horizon of Aton' (Belmonte et al., 2009, p. 232).

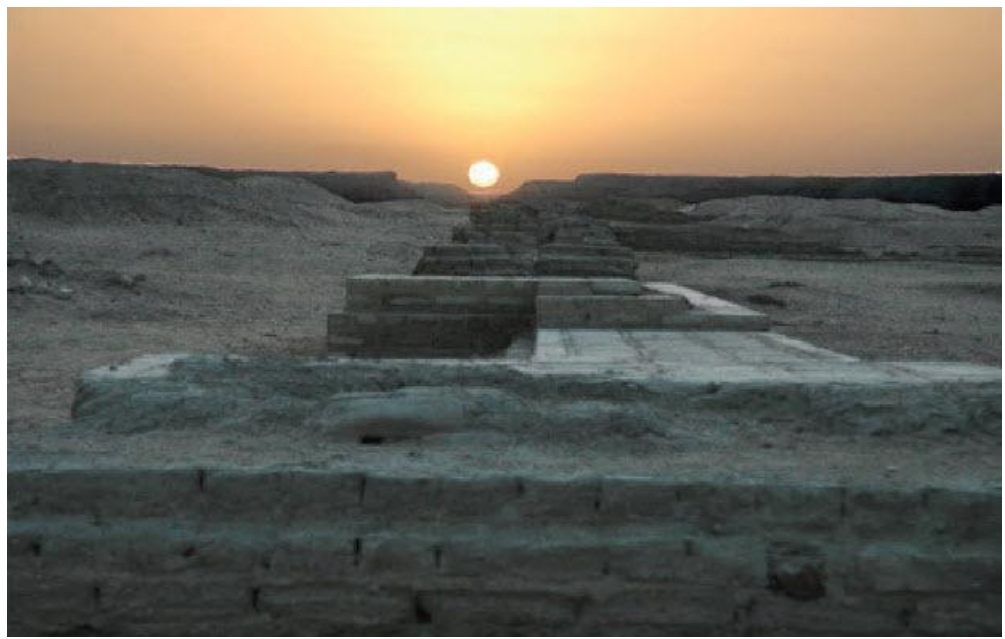


Kambon, B. O. \& Asare, Y. M./Legon Journal of the Humanities Vol. 30.2 (2019)

Figure 7: the temple is oriented toward a cleft in the horizon where the royal tomb was excavated, which is the precise spot where the sun rises in late February and October (Photograph courtesy of M. Gabolde) in (Belmonte et al., 2009, p. 232)

While one may be inclined to think that temple orientations such as those mentioned above were perhaps random or happenstance, as can be seen from the graph above, out of 330 temples surveyed by Belmonte, et. al (2009, p. 223), there are clear and obvious statistically significant peaks near the 'equinoctial' sunrise (due-East) and the winter solstice (WS) sunrise, which is equated to the due-North orientation skewed by $90^{\circ}$. There are also clear peaks at SE and NE showing clear evidence of intentional astronomical/solar orientations of temples as shown in Figure 8.

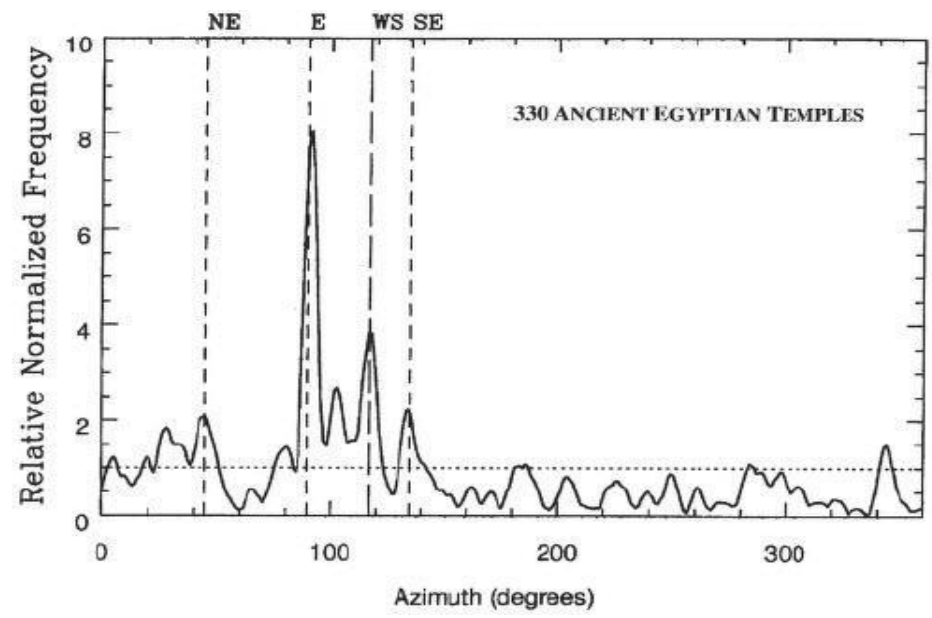

Figure 8: Chart illustrating 330 Solar and Celestial Temple Orientations (Belmonte,

Shaltout, \& Fekri, 2009, p. 223)

\section{Celestial (Stellar) Alignment}

We will now turn our attention to the orientation of temples vis-à-vis celestial phenomena. In Belmonte et al.'s research, there were definite correlations between

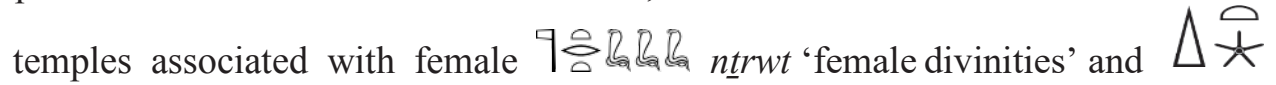
$s p d t$ 'Sopdet/Sirius'. Likewise, there were clear orientations toward equinoxes and solstices for solar-related $¥$ $n \underline{t} r w$ 'male divinities.' This is shown in Figure 11, which illustrates the absolute declination histograms 34 temples of 'female divinities' and 42 temples of 9 ำtrw 'male divinities' of solar character, respectively (Belmonte, et. al 2009: 226). 


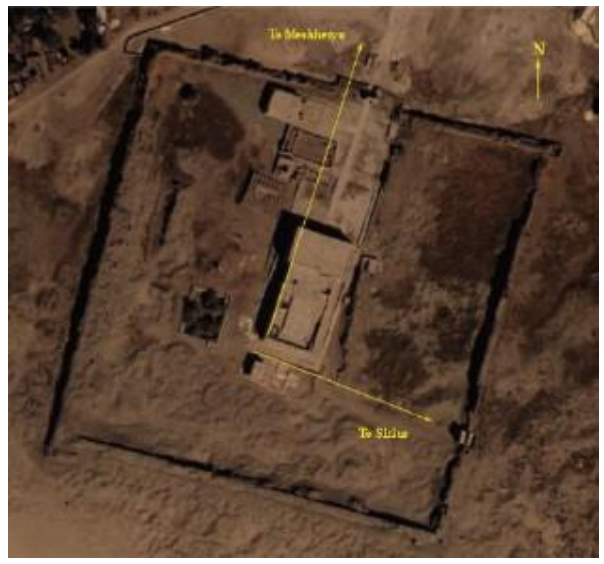

Figure 9: The complex of the temple of Hathor at Dendara (Belmonte et al., 2009, p. 235)

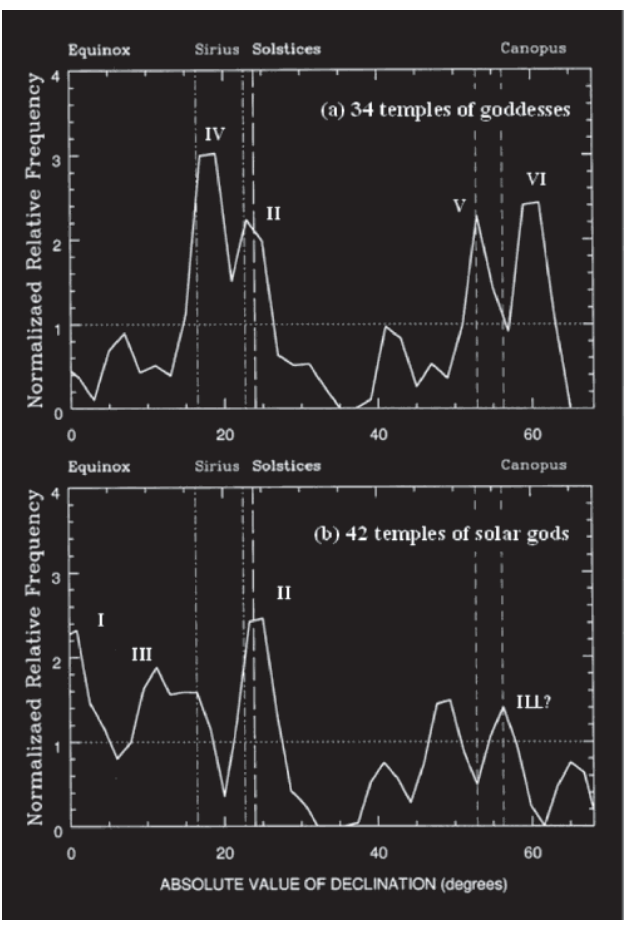

Figure 10: "Absolute declination histograms of two independent series of temples. (a) 34 temples of goddesses of all periods. (b) 42 temples of divinities with a solar character. Notice the most significant peak corresponding to Sopdet family for series (a)" (Belmonte et al., 2009, p. 226)

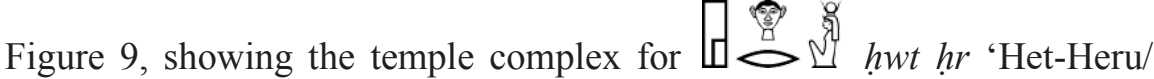
Hathor' at Dendara shows the main building, orientated north, in the direction of f $^{\Omega}{ }^{\wedge}$ mshtyw 'Meshketyu' in the direction that it was located in the late Ptolemaic period (Belmonte et al., 2009, p. 234). The small temple dedicated to

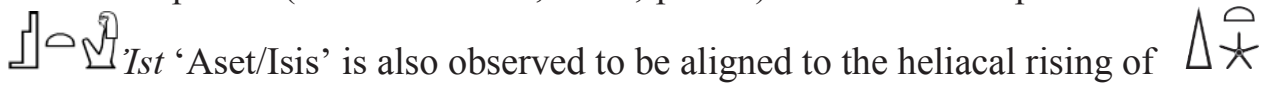
$s p d t$ 'Sopdet/Sirius as it is not exactly perpendicular to the main temple (Belmonte et al., 2009, p. 234).

The significance of these alignments is explained in detail as follows:

The god Sah personified the constellation of Orion - the most distinctive of all the constellations in the night sky. While not part of the 'imperishable' circumpolar stars, the constellation became important in Egyptian mythology especially as it 
Kambon, B. O. \& Asare, Y. M./Legon Journal of the Humanities Vol. 30.2 (2019)

rose directly before the adjacent star Sirius (the Egyptian Sothis) - the brightest fixed star which was utilized in the calculation of the Egyptian calendar. The constellation god was thus connected with the star Sothis from an early date and the two came to be viewed as manifestations of Osiris and Isis respectively (Wilkinson, 2003, p. 127).

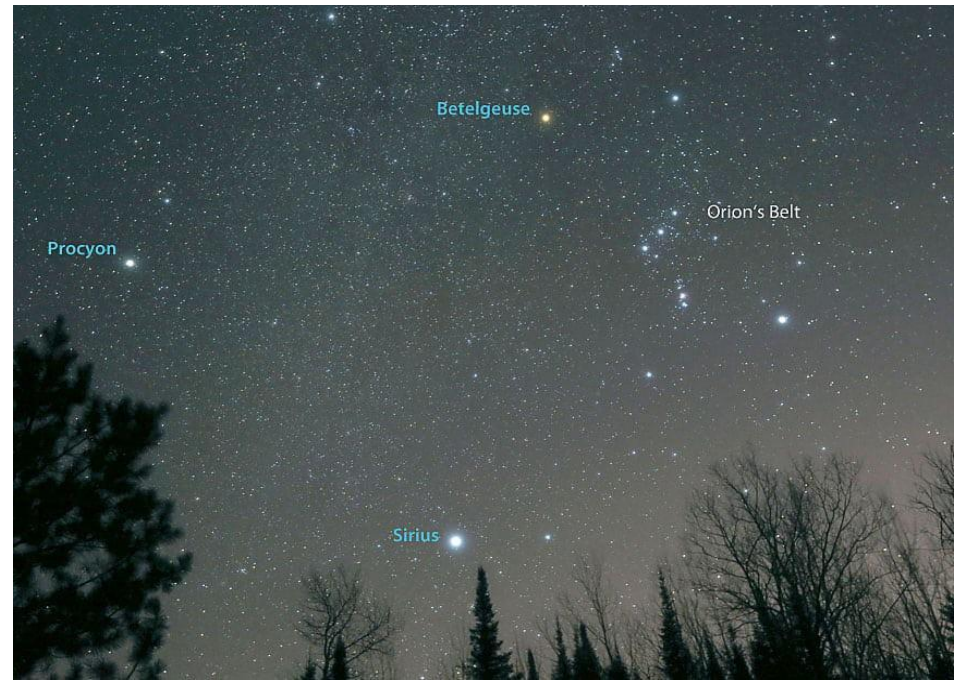

Figure 11: Three stars in Orion's belt pointing through Sirius to the location of the Sunrise at the Winter Solstice (King, 2018)

Interestingly, the three (3) stars in the belt of 2 ?

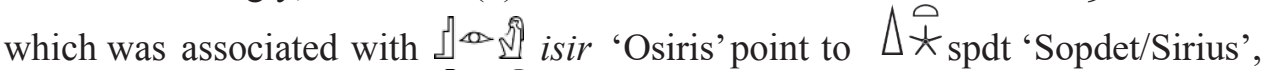

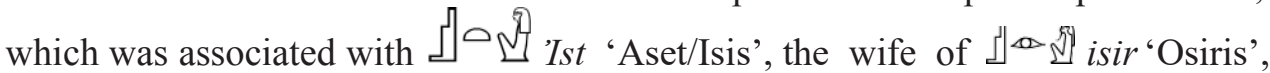
and this line points to where the $h r w$ 'Horus/The Sun', associated with the sun, rises at dawn during the winter solstice in the south-eastern sky as shown in Figure 11.

Thus, we find that temples to ปด 'Ist 'Aset/Isis' are orientated towards $\Delta \star s p d t$ 'Sopdet/Sirius', as shown in Figure 10 as this is the star system with which she was associated. Similarly, as also shown in Figure 10, temples associated with solar divinities are oriented toward hrw 'Horus/The Sun'. 
Kambon, B. O. \& Asare, Y. M./Humanities and Sciences as Complementary Aspects of an Afrikan=Black Whole: Evidence from Archeoastronomy

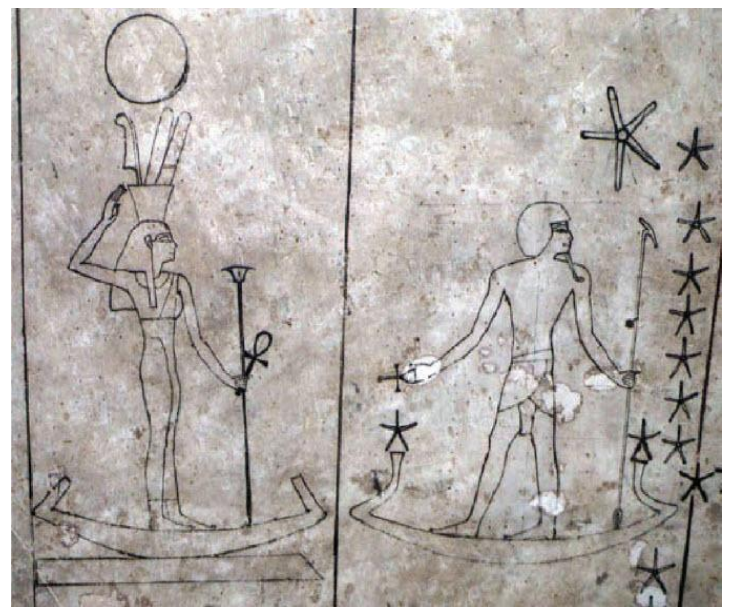

Figure 12: Sopdet and Sah on the astronomical ceiling of the tomb of Senenmut in

Deir el Bahari (Photo Credit Belmonte et al., 2009, p. 217)

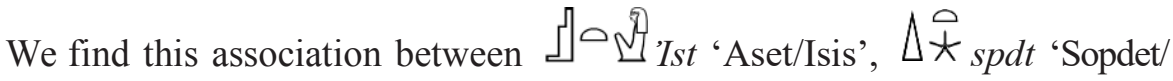
Sirius' and monuments oriented toward Sirius in other instances as well. As noted by Belmonte et al. (2009), "The goddess Sopdet standing for Sirius, the brightest star of the Egyptian firmament, and the god Sah (southern part of Orion), as beautifully depicted in the astronomical ceiling of the tomb of Senenmut in Deir el Bahari, one of several monuments oriented towards Sirius in the geography of Egypt" (p. 217).

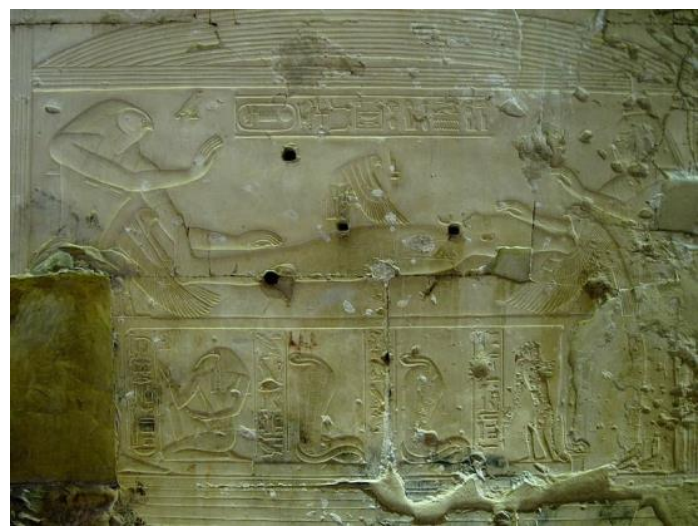

Figure 13: Original "Immaculate Conception" concept of Ist as kite alighting on the phallus of Asr with the spirit form of Hrw to the left at the temple of Seti I. (Tausch, 2011) 
Here, again, we see the link between the so-called sciences (i.e., astronomy) and the so-called humanities in architecture as well as in other depictions of the astronomical phenomena. These connections are highlighted in that the interrelation

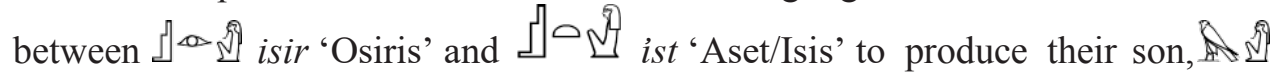
hrrw 'Horus/The Sun' was depicted as a virgin birth as illustrated in Figure 13. The story of the original "immaculate conception", which is an allegory referring to the Sun's Death and Resurrection at the Winter Solstice is found in the world's oldest spiritual texts, the Pyramid Texts, where it is stated that: "Isis comes to you rejoicing through love of you; your seed issues into her, she being ready as Sothis. Har-Sopd has issued from you in his name of "Horus who is in Sothis."' (Faulkner, 1969, p. 244)

\section{Pyramid Alignments}

Before delving into the alignments between pyramids and celestial and/or terrestrial phenomena, it behooves us to first take into account that the construction of the pyramids was a set of fundamentally Humanistic projects that were at the same time, the world's first and largest recorded testable science experiments. Articulated more clearly, the goal of the pyramids was to send the $3 \mathrm{~h}$ ' effective spirit' of the deceased ruler to the imperishable stars by constructing structures in alignment with those stars that never set below the horizon. The idea was that on the premise of "As above, so below," since stars have an impact on the lives of those on earth, if the ruler in spirit form could go and join these stars that are always seen in the firmament, then the ruler could continue to advocate for and intercede on behalf of those still on earth. The pyramid texts are replete with references to the ruler joining the imperishable stars to these ends. The following texts come from the oldest known of all of these, the pyramid text of nswt bity Wnis, inscribed within approximately 2345-2315 все:

Humanity will cry out to you once the Imperishable Stars have raised you aloft. (Allen, 2015, p. 34)

See me, as you have seen the forms of the progeny who know their spells, the Imperishable Stars, and see (in me) the two in the palace - that is, Horus and Seth. (Allen, 2015, p. 34)

The portals act for me, the (Red Crown's) coil is tied on for me, and I lead the Imperishable Stars. (Allen, 2015, p. 52)

I go up on Isis's thighs, I climb on Nephthys's thighs. My father Atum takes my arm and allots me to those gods who are wise and experienced, the Imperishable Stars (Allen, 2015, p. 53) 
Kambon, B. O. \& Asare, Y. M./Humanities and Sciences as Complementary Aspects of an Afrikan=Black Whole: Evidence from Archeoastronomy

In addition to temples aligned with solar and celestial phenomena, massive 命 $m r w$ 'pyramids' are also demonstrated to have been constructed with precise scientific and mathematical precision. This is shown in Figure 14. Quoting Browder (1992),

One of the most precisely constructed passages in the pyramid is the Descending Passage [...] Two shafts were cut through 200 feet of solid masonry to the outer surface of the pyramid. These shafts, which face in a northerly and southerly direction, have long been regarded as "air shafts" that ventilated the King's Chamber. New evidence has been presented which shows the so-called air shafts are inclined, within one degree of accuracy, to the northern celestial pole, and to the three stars of Orion's Belt to the south. The main star viewed through the northern shaft is called Alpha Draconis. Around it turned the Circumpolars (often railed the "Indestructibles" because they never disappeared below the horizon). It was for this reason that these stars symbolized immortality. A soul which had chosen this path in life was said to ascend into the imperishable dominion of the northern heavens (Browder, 1992, pp. 108-109).

These alignments have led several scholars to posit dates for the construction of the great pyramid of Giza based on when it has been calculated that the so-called air shafts would have been pointing to these stars as shown below:

Table 1: Dating of the Great Pyramid based on Celestial Alignments

\begin{tabular}{|l|l|}
\hline Author & Date using shafts \\
\hline Virginia Trimble (1964) & 2600 вСЕ \\
\hline Alexander Badawy (1965) & 2600 вСе \\
\hline Robert Bauval \& Gilbert (1994) & 2450 вСе $+/-25$ \\
\hline Mary Bruck (1995) & 2450 вСЕ $+/-60$ \\
\hline Kate Spence (2000) & 2478 вСЕ $+/-5$ \\
\hline
\end{tabular}

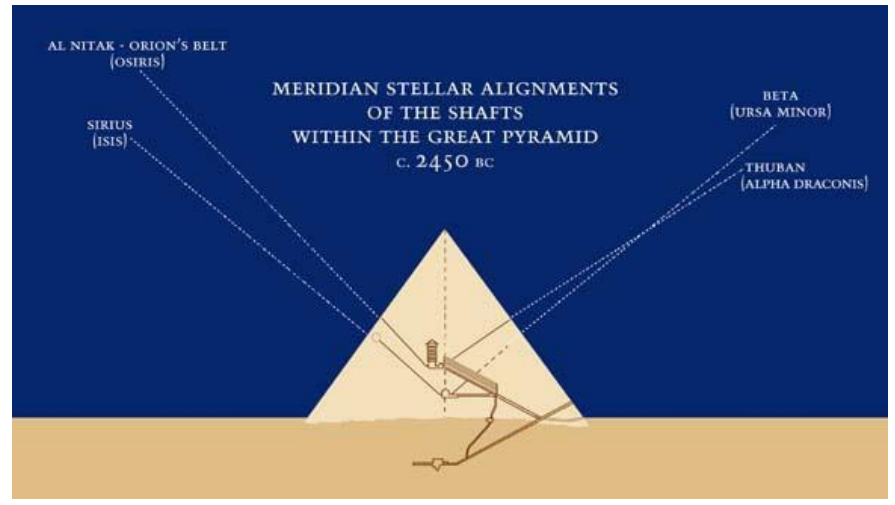

Figure 14: Great pyramid celestial alignments (McKenty, 2000) 
The calculations made as presented in Table 1 and illustrated in Figure 14 give insight into the relationship between areas contemporarily known to be within the area of the so-called Humanities and those of the so-called Sciences. Interestingly, recent research has shown that not only were the pyramids constructed with reference to celestial phenomena, they were also aligned with each other and other terrestrial phenomena. In other words, archaeoastronomy is further complemented by what we may term archaeogeography. This can be seen clearly in the pyramidal alignment pointing to $i w n w$ 'Heliopolis' as shown in Figure 16 and Figure 17.

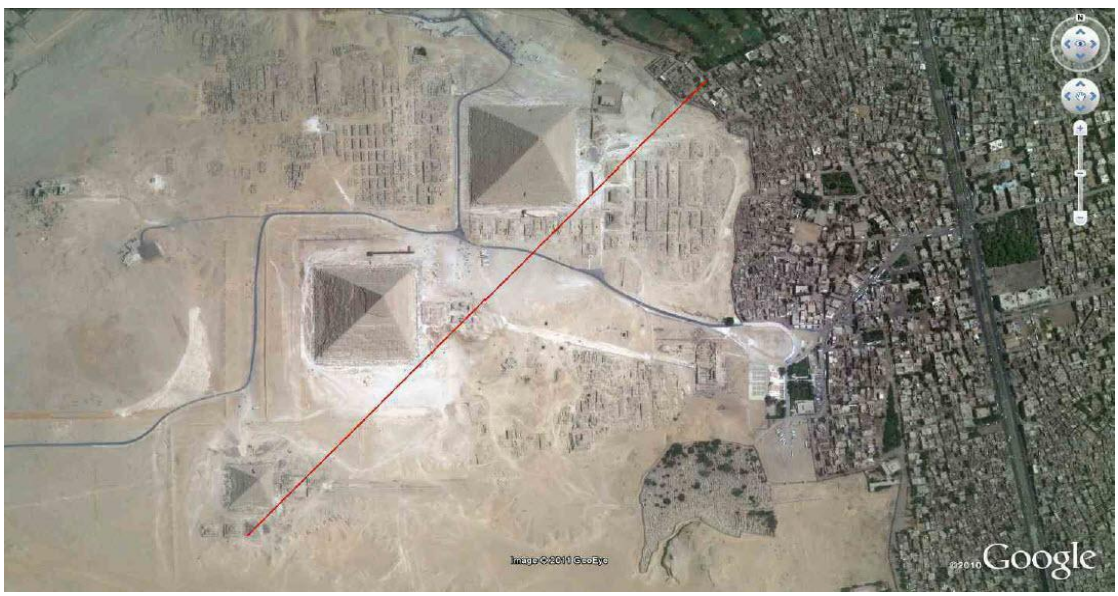

Figure 15: Intra-Alignment of Great Pyramids of Giza (Magli, 2011, p. 6)

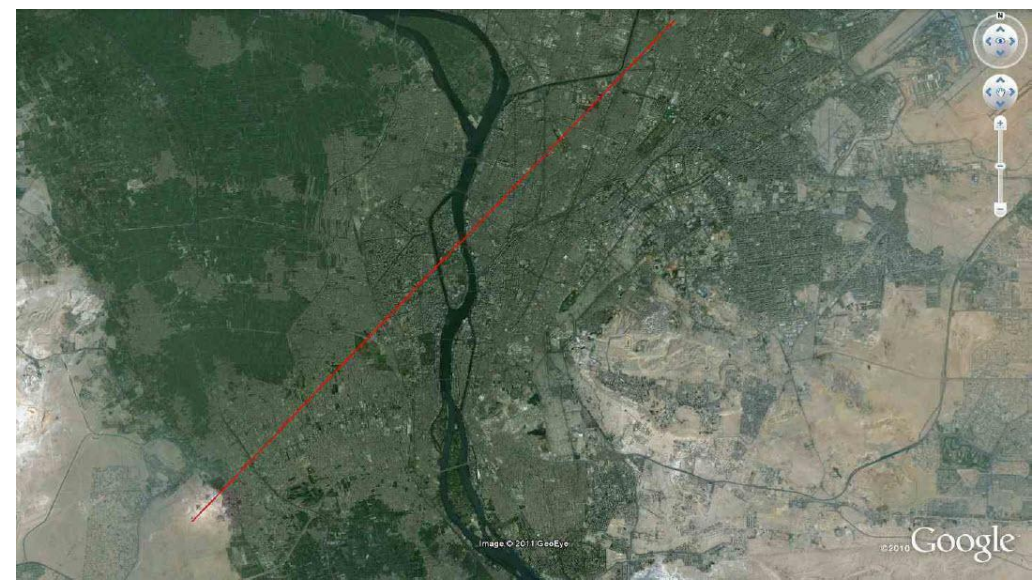

Figure 16: Alignment of Great Pyramids with reference to the txn 'obelisk' of iwnw 'Heliopolis' (Magli, 2011, p. 6) 
Kambon, B. O. \& Asare, Y. M./Humanities and Sciences as Complementary Aspects of an Afrikan=Black Whole: Evidence from Archeoastronomy

Even more remarkably, these alignments are not only restricted to the pyramids and ${ }^{2}$ iwnw 'Heliopolis', but extend far afield to monuments throughout the area, which are oriented to point toward $\mathrm{H}_{\mathrm{Q}} i w n w$ 'Heliopolis', the ancient spiritual capital and location of the temple of $2 \odot \mathcal{A}^{\varsigma}$.

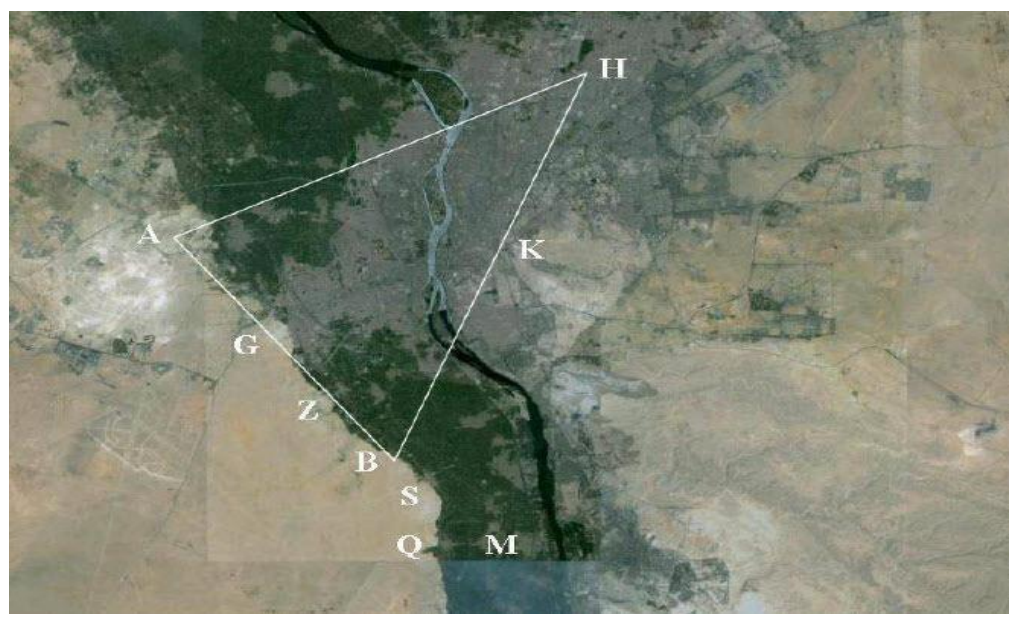

Figure 17: The geographical area of interest: H=Heliopolis, $K=$ Cairo Citadel, $A=$ Abu Roash, $G=$ Giza, $Z=$ Zawiet el Arian, $B=$ Abu Gorab, $S=A b u$ Sir, $Q=$ Saqqara main field, M=Memphis (Magli, 2009, p. 4)

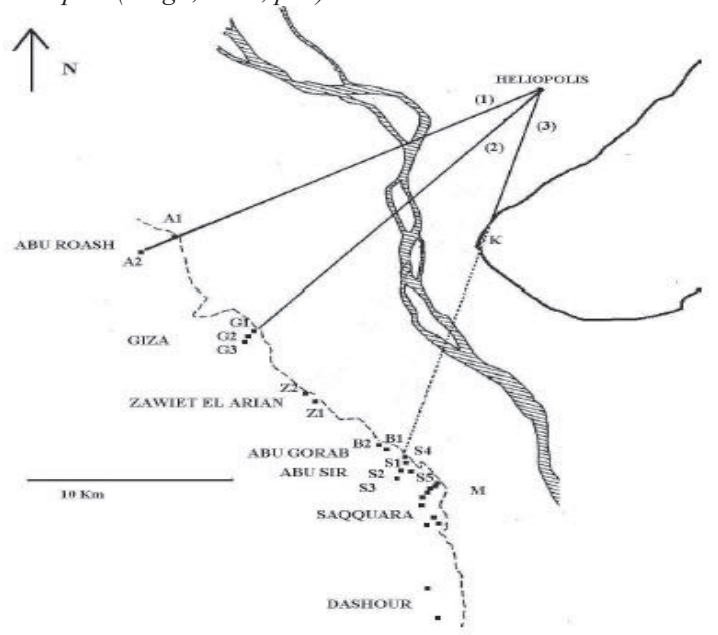

Figure 18: The pyramids, the Sun Temples and the Heliopolitan 'diagonals': (1) Abu Roash diagonal, (2) Giza diagonal, (3) Abusir diagonal. The dotted straight line denotes invisibility. The stepped line denotes the maximal Nile flood (Magli, 2009, p. 7) 
Making the point even more vividly is the fact that there is no direct line of sight between Abu Sir and Heliopolis, meaning that the calculations had to be reckoned mathematically.

\section{Conclusion}

We argue that our acceptance of a compartmentalized false dichotomy between the so-called Humanities and the Sciences constitutes pale white Eurasianinduced conceptual incarceration which impedes a holistic Afrikan view of complementary aspects of a necessary whole. For Afrikans=Black people, astronomy and associated mathematical calculations influenced architecture, literature, etc. Further, the so-called Humanities (spirituality, philosophy, literature, etc.) influenced how astronomy was understood. As such, a recognition of the interrelations and interdependence of the Humanities and the Sciences is not a future ideal to be attained, but rather a past reality which, once known, can inform our trajectories and actions. The significance of this knowledge is that as unapologetically committed Afrikan=Black researchers, our commitment is that towards the re-membering of Afrikan people throughout space, time, energy and matter. This endeavour requires the concomitant re-membering of Afrikan=Black knowledge production systems and their application in our reality. This will be a great contribution to the total liberation of Afrikans wherever we may be. In such a Sankofa 'Go back and fetch it' movement, the so-called Sciences and the socalled Humanities should no longer necessarily be viewed as disparate phenomena, but rather be seen once again as complementary aspects of an Afrikan=Black whole for the restoration of $\Rightarrow M_{3}^{s} t$ on Earth as she exists in the Celestial Sphere. 


\section{References}

Allen, J. P. (2015). The Ancient Egyptian Pyramid Texts. Atlanta: SBL Press.

Ani, M. (1994). Yurugu: An African Centred Critique of European Cultural Thought and Behavior. Trenton, NJ: Africa WorldBooks.

Badawy, A. (1965). Ancient Egyptian architectural design: a study of the harmonic system (Vol. 4). Oakland, CA: University of California Press.

Bauval, R., \& Gilbert, A. (1994). The Orion mystery: unlocking the secrets of the pyramids. New York: Three Rivers Press.

Beatty, M. (1997). Maat: The cultural and intellectual allegiance of a concept. In J. H. Carruthers \& L. C. Harris (Eds.), The preliminary challenge: World history project (pp. 211-244). Los Angeles: Association for the Study of Classical African Civilizations Kemetic Institute.

Belmonte, J. A., \& Shaltout, M. (2010). Keeping Ma'at: An astronomical approach to the orientation of the temples in ancient Egypt. Advances in Space Research, 46(4), 532-539.

Belmonte, J. A., Shaltout, M., \& Fekri, M. (2009). Astronomy, landscape and symbolism: a study of the orientation of ancient Egyptian temples. In search of cosmic order: Selected essays on Egyptian archaeoastronomy, 1, 213.

Brophy, T. G., \& Rosen, P. A. (2005). Satellite imagery measures of the astronomically aligned megaliths at Nabta Playa. Mediterranean archaeology and archaeometry, 5(1), 15-24.

Browder, A. T. (1992). Nile Valley Contributions to Civilization: Exploding the Myth (Vol. 1). Washington, DC: Institute of Karmic Guidance.

Bruck, M. T. (1995). Can the Great Pyramid be astronomically dated? Journal of the British Astronomical Association, 105, 161-164.

Carruthers, J. H. (1989). Essays in ancient Egyptian studies. Los Angeles, CA: University of Sankore Press.

Carruthers, J. H. (1999). Intellectual Warfare. Chicago: Third World Press.

Chandler, W. B. (2000). Ancient Future: The Teachings and Prophetic Wisdom of the Seven Hermetic Laws of Ancient Egypt. Baltimore, MD: Black Classic Press.

Diop, C. A., \& Cook, M. (1989). The African Origin of Civilization: Myth Or Reality. Chicago: Chicago Review Press.

Etymonline. (2018). Science. Retrieved from https://www.etymonline.com/word/ science 
Kambon, B. O. \& Asare, Y. M./Legon Journal of the Humanities Vol. 30.2 (2019)

Faulkner, R. O. (1969). The Pyramid Texts. Oxford: Oxford University Press.

Finch, C. (1998). The star of deep beginnings: The genesis of African science and technology. Decatur, GA: Khenti, Incorporated.

Graham, K. (2016, 21 January 2019). Evidence of earliest massacre found dates back 10,000 years. Retrieved from http://www.digitaljournal.com/ science/evidence-of-earliest-massacre-found-dates-back-10-000-years/ article/455457\#ixzz67UOA6uJY

Griaule, M. (1934 (1970)). Conversations with Ogotemmeli: An introduction to Dogon religious ideas. Oxford: Oxford University Press.

Harrell, J. A., \& Brown, V. M. (1992a). The oldest surviving topographical map from ancient Egypt:(Turin Papyri 1879, 1899, and 1969). Journal of the American Research Center in Egypt, 29, 81-105.

Harrell, J. A., \& Brown, V. M. (1992b). The World's oldest surviving geological map: the 1150 BC Turin Papyrus from Egypt. The Journal of Geology, 100(1), 3-18.

Hilliard, A. G. (1998). SBA: The reawakening of the African mind: Makare Pub Co.

Kambon, O. (2017). Akan Ananse Stories, Yorùbá İjàpá Tales, and the Dikenga Theory: Worldview and Structure. Contemporary Journal of African Studies, $4(2), 1-36$.

King, B. (2018). The Winter Triangle Meets The Preposterous Monoceros. Retrieved from https://astrobob.areavoices.com/2018/02/11/the-winter-triangle-meetsthe-preposterous-monoceros/

Kreamer, C. M. (2012). African cosmos: stellar arts. New York: Monacelli Press.

Lynch, B., \& Robbins, L. (1978). Namoratunga: The first archeoastronomical evidence in sub-Saharan Africa. Science, 200(4343), 766-768.

Magli, G. (2009). Topography, astronomy and dynastic history in the alignments of the pyramid fields of the Old Kingdom. arXiv preprint arXiv:0903.1416.

Magli, G. (2011). Reconstruction of ancient conceptual landscapes in the Nile Valley. arXiv preprint arXiv:1104.1785.

Martin, D. (2008). Maat and Order in African Cosmology: A Conceptual Tool for Understanding Indigenous Knowledge. Journal of Black Studies, 38(6), 951967. doi: $10.2307 / 40035033$

McK Malville, J., Schild, R., Wendorf, F., \& Brenmer, R. (2007). Astronomy of Nabta Playa. African Skies, 11, 2. 
Kambon, B. O. \& Asare, Y. M./Humanities and Sciences as Complementary Aspects of an Afrikan=Black Whole: Evidence from Archeoastronomy

McKenty, R. (2000). Are The Pyramids Of Giza Aligned With The Sun And The Stars? Yes. Retrieved from http://www.merriam-webster.com/dictionary/ complementary

McMahon, D. (1992). The Turin Papyrus Map The Oldest Known Map with Geological Significance. Earth Sciences History, 11(1), 9-12.

Merriam-Webster. (2018a). Complementary. Retrieved from http://www.merriamwebster.com/dictionary/complementary

Merriam-Webster. (2018b). Humanities. Retrieved from http://www.merriamwebster.com/dictionary/humanity

Montgomery, A. B. (2017). An Examination of Ra Emerging from Nu. Words Spoken by the Imy-Wenewity. The African Star-Watchers Who Invented “Time!". Detroit: lulu.com / the Medew Netcher Study Group, Inc.

Museum, B. (Cartographer). (2019). Map of cemetery 117 at Jebel Sahaba [

]. Retrieved from https://blog.britishmuseum.org/violence-and-climatechange-in-prehistoric-egypt-and-sudan/

Obenga, T. (2004). African Philosophy: The Pharaonic period, 2780-330 B.C.

Popenguine, Senegal: Per Ankh.

Spence, K. (2000). Ancient Egyptian chronology and the astronomical orientation of pyramids. Nature, 408(6810), 320-324.

Stevenson, A. (2010). Oxford Dictionary of English. Oxford: OUP Oxford.

Tausch, O. (2011). Abydos Tempelrelief Sethos I (pp. Deutsch: Relief der Erweckung des Gottes Osiris durch die Göttin Isis im Totentempel Sethos I. in Abydos, Ägypten Čeština: Eset v podobě ptáka kopuluje se zesnulým Usirem. Na levé straně je Hor, přestože $v$ té době ještě nebyl narozen, a na straně druhé Eset v lidské podobě. Chrám Sethiho I., Abydos). Web: Wikimedia Commons.

Trimble, V. (1964). Astronomical Investigation Concerning the So-Called AirShafts of Cheops' Pyramid. Mitteilungen der Institut Fur Orientforschung, 10(2/3), 183-187.

Van Sertima, I. (1983). Blacks in science: Ancient and modern. New Brunswick, NJ: Transaction Publishers.

Van Sertima, I. (1994). Egypt: Child of Africa. New Brunswick, NJ:

TransactionPublishers.

Waite, M. (2009). Oxford Thesaurus of English. Oxford: OUP Oxford. 
Kambon, B. O. \& Asare, Y. M./Legon Journal of the Humanities Vol. 30.2 (2019)

Wilkinson, R. H. (2003). The Complete Gods and Goddesses of Ancient Egypt. London: Thames and Hudson.

Womack, Y. (2013). Afrofuturism: The world of Black sci-fi and fantasy culture. Chicago: Chicago Review Press. 